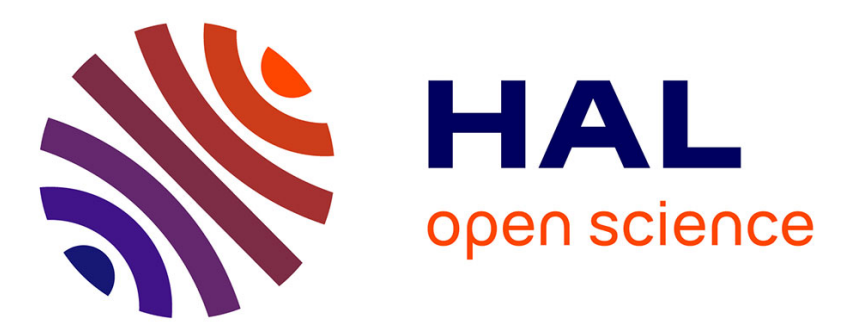

\title{
Androgen receptor signalling in prostate: effects of stromal factors on normal and cancer stem cells
}

\author{
Paul A Berry, Norman J. Maitland, Anne T. Collins
}

\section{To cite this version:}

Paul A Berry, Norman J. Maitland, Anne T. Collins. Androgen receptor signalling in prostate: effects of stromal factors on normal and cancer stem cells. Molecular and Cellular Endocrinology, 2008, 288 (1-2), pp.30. 10.1016/j.mce.2008.02.024 . hal-00532010

\section{HAL Id: hal-00532010 https://hal.science/hal-00532010}

Submitted on 4 Nov 2010

HAL is a multi-disciplinary open access archive for the deposit and dissemination of scientific research documents, whether they are published or not. The documents may come from teaching and research institutions in France or abroad, or from public or private research centers.
L'archive ouverte pluridisciplinaire HAL, est destinée au dépôt et à la diffusion de documents scientifiques de niveau recherche, publiés ou non, émanant des établissements d'enseignement et de recherche français ou étrangers, des laboratoires publics ou privés. 


\section{Accepted Manuscript}

Title: Androgen receptor signalling in prostate: effects of stromal factors on normal and cancer stem cells

Authors: Paul A Berry, Norman J. Maitland, Anne T. Collins

PII: $\quad$ S0303-7207(08)00113-5

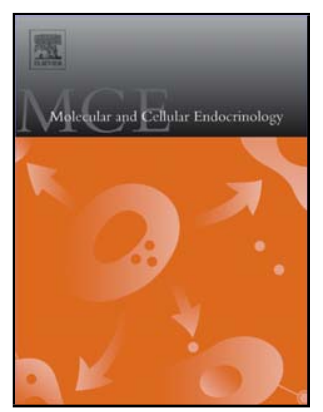

DOI: doi:10.1016/j.mce.2008.02.024

Reference: MCE 6838

To appear in: $\quad$ Molecular and Cellular Endocrinology

Received date: 6-2-2008

Revised date: 26-2-2008

Accepted date: $\quad$ 26-2-2008

Please cite this article as: Berry, P.A., Maitland, N.J., Collins, A.T., Androgen receptor signalling in prostate: effects of stromal factors on normal and cancer stem cells, Molecular and Cellular Endocrinology (2007), doi:10.1016/j.mce.2008.02.024

This is a PDF file of an unedited manuscript that has been accepted for publication. As a service to our customers we are providing this early version of the manuscript. The manuscript will undergo copyediting, typesetting, and review of the resulting proof before it is published in its final form. Please note that during the production process errors may be discovered which could affect the content, and all legal disclaimers that apply to the journal pertain. 


\section{ANDROGEN RECEPTOR SIGNALLING IN PROSTATE: EFFECTS OF STROMAL FACTORS ON NORMAL AND CANCER STEM CELLS}

Paul A Berry, Norman J Maitland and Anne T Collins

YCR Cancer Research unit, Department of Biology, University of York, Wentworth Way, York, YO10 5DD, UK.

\section{Abstract}

The prostate gland is the most common site for cancer in males within the developed world. Androgens play a vital role in prostate development, maintenance of tissue function and pathogenesis of prostate disease. The androgen receptor signalling pathway facilitates that role in both the epithelial compartment and in the underlying stroma. Stroma is a key mediator of androgenic effects upon the epithelium and can regulate both the fate of the epithelial stem cell and potentially the initiation and progression of prostate cancer. Different groups of growth factors are expressed by stroma, which control proliferation, and differentiation of prostate epithelium demonstrating a critical role for stroma in epithelial growth and homeostasis. Paracrine stromal proteins may offer the possibility to control tumour stem cell growth and could permit prostate-specific targeting of both therapies and of androgenresponsive proteins. The effect of $5 \alpha$-dihydrotestosterone, the more potent metabolite of testosterone, on expression of androgen regulated genes in stroma from benign prostatic hyperplasia is a key mediator of epithelial cell fate. Global gene expression arrays have recently identified new candidate genes in androgen responsive stroma, some of which have androgen receptor binding sites in their promoter regions. Some of these genes have direct androgen receptor binding ability.

Keywords: Prostate, (cancer stem cell), androgen, paracrine growth factors, (stroma)

\section{Contents}

1. The Prostate gland and pathology

2. Prostate architecture

3.1 Stromal epithelial interactions in the prostate

3.2 Paracrine growth factors

3.2a Transforming growth factor $\beta$

3.2b Platelet derived growth factor

3.2c Fibroblast growth factors

3.2d Epidermal growth factor

3.2e Hepatocyte growth factor

$3.2 f$ Insulin like growth factor

3.2g Caveolin 1

3.2h Hypoxia inducible factor 
3.2i Interleukin 6

3.2j Vascular endothelial growth factor

3.3 Global gene expression analysis of BPH prostate stroma

3.4 Cancer reactive stroma

4.1 Androgen receptor signalling pathway

4.2 Androgen receptor mutations

5.0 Conclusions

List of abbreviation

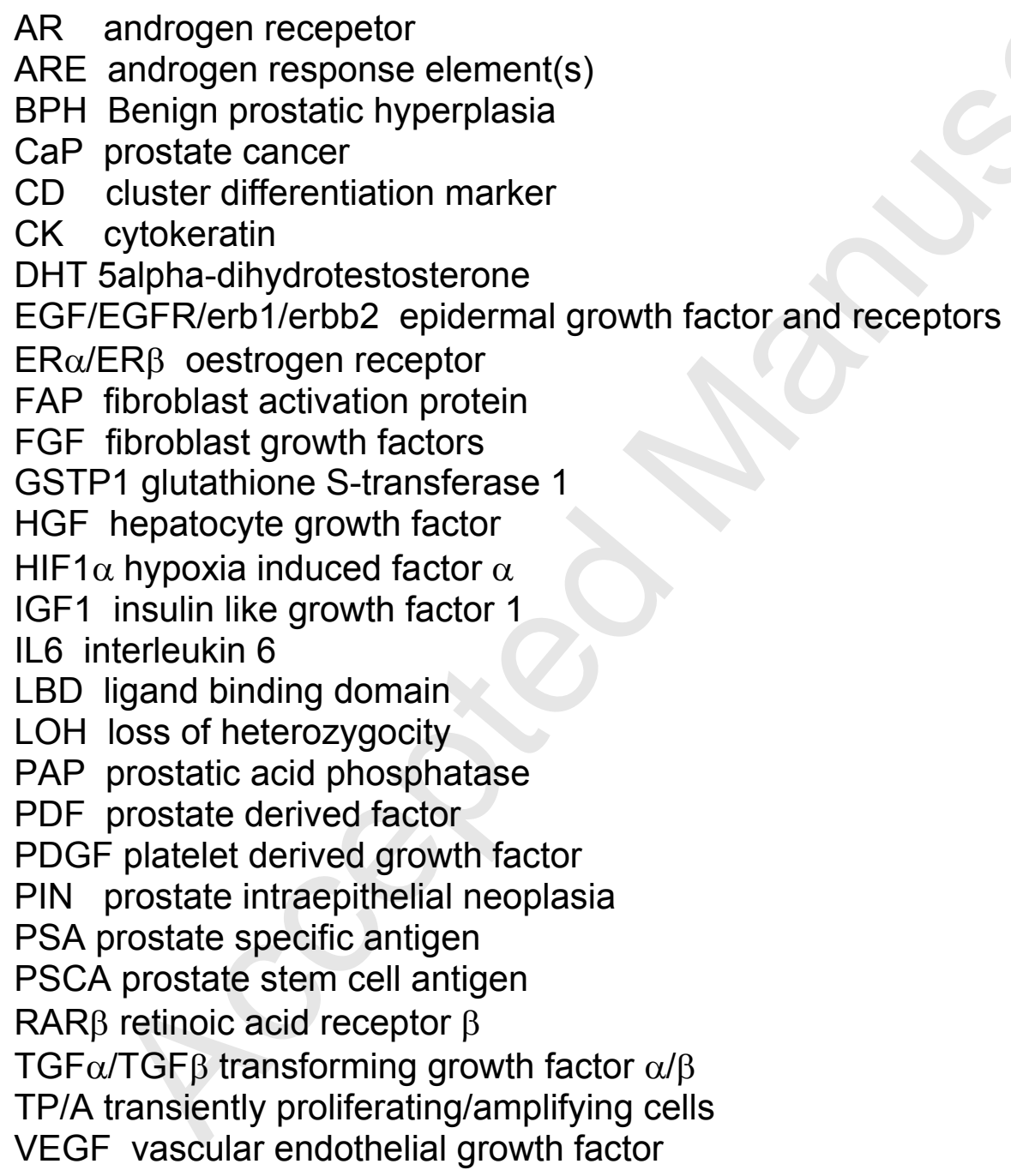

AR androgen recepetor

ARE androgen response element(s)

$\mathrm{BPH}$ Benign prostatic hyperplasia

$\mathrm{CaP}$ prostate cancer

$\mathrm{CD}$ cluster differentiation marker

CK cytokeratin

DHT 5alpha-dihydrotestosterone

EGF/EGFR/erb1/erbb2 epidermal growth factor and receptors

$E R \alpha / E R \beta$ oestrogen receptor

FAP fibroblast activation protein

FGF fibroblast growth factors

GSTP1 glutathione S-transferase 1

HGF hepatocyte growth factor

HIF1 $\alpha$ hypoxia induced factor $\alpha$

IGF1 insulin like growth factor 1

IL6 interleukin 6

LBD ligand binding domain

LOH loss of heterozygocity

PAP prostatic acid phosphatase

PDF prostate derived factor

PDGF platelet derived growth factor

PIN prostate intraepithelial neoplasia

PSA prostate specific antigen

PSCA prostate stem cell antigen

RAR $\beta$ retinoic acid receptor $\beta$

TGF $\alpha /$ TGF $\beta$ transforming growth factor $\alpha / \beta$

TP/A transiently proliferating/amplifying cells

VEGF vascular endothelial growth factor 


\section{THE PROSTATE GLAND AND PATHOLOGY}

The prostate gland is the most common site of neoplastic disorders in men, which mainly develop after the age of 50 . By this time, half of men will have a degree of benign prostate hyperplasia (BPH). At 80 years of age, $90 \%$ of men will have BPH symptoms (Rizzo et al, 2005) and $23 \%$ of men will develop prostate cancer $(\mathrm{CaP})$. CaP is now the most common cancer in men. Within the UK, 32,000 men were diagnosed with CaP in 2004, representing $12 \%$ of cancer incidence (Cancer Research UK). Increasingly, amongst the elderly male population prostate disease is having a significant effect on morbidity, mortality and health care resources.

The pathogenesis of $\mathrm{BPH}$ and $\mathrm{CaP}$ is still poorly understood (Bonkhoff and Remberger, 1996). In BPH there is an androgen-mediated proliferation of the anterior prostate lobe possibly in response to decreasing levels of androgen, and changes in the balance between epithelial cell division and differentiation (Rizzo et al, 2005). This leads to symptoms of bladder outflow obstruction and abdominal pain, which are the most common referral reasons. A recent review even proposes mechanical urethral angulation to be a causative factor (Cho et al, 2007). BPH is not a precursor for $\mathrm{CaP}$, other precursor lesions are recognised and are discussed below. Current therapeutic options for $\mathrm{CaP}$ remain inadequate (Chung et al, 2003). While tumours initially respond well to androgen reduction, the duration of response is short, typically 12-33 months. At this time a population of cells resistant to androgen deprivation therapy emerges (Rizzo et al, 2005).

Prostatic intraepithelial neoplasia (PIN) represents a precursor lesion for invasive $\mathrm{CaP}$ development. This lesion is characterized by expression of bcl2, c-Met and nuclear phosphoprotein pp32 (Bui and Reiter, 1999). A low grade PIN lesion is often a well differentiated early invasive tumour with a high percentage of basal cells. The high grade lesions form poorly differentiated tumours with a secretory luminal cell population (Bonkhoff and Remberger, 1996).

\section{PROSTATE ARCHITECTURE}

The normal prostate is a walnut sized gland composed of different cell types that can be distinguished by their cytokeratin (CK) and cluster differentiation (CD) expression patterns. Three main cell types are discernible within normal, mature prostatic epithelium - basal, secretory luminal and neuroendocrine. The luminal or glandular cells constitute the exocrine compartment of the prostate, secreting prostate specific antigen (PSA) and prostatic acid phosphatase (PAP) into the glandular lumina. They are terminally differentiated, and represent the major cell type in normal and hyperplastic epithelium. They express high levels of the androgen receptor (AR), and depend on androgens for their survival (Collins and Maitland, 2006). They also express CK-8 and CK-18. 
In contrast, basal cells are relatively undifferentiated and lack secretory activity. As their name suggests, basal cells rest on the basement membrane and morphologically range from small flattened to cuboidal cells. They express low/undetectable levels of AR (Bonkhoff and Remberger, 1996) and are independent of androgens for their survival (Collins and Maitland, 2006). Basal cells focally express the oestrogen receptor and can proliferate under oestrogen therapy (Collins and Maitland, 2006). Basal cells express CK-5, CK-14, CD44, p63, a homologue of the tumour suppressor gene $p 53$, and the anti-apoptotic protein bcl-2. Basal cells do not express androgen receptor (AR), although there may be focal expression of nuclear oestrogen, progesterone, and glucocorticoid receptors (Bonkhoff and Remberger, 1996), and hence they are androgenindependent. Within this basal compartment are the epithelial stem cells and transiently proliferating/amplifying (TP/A) cells expressing CK-5, CK-18, CK-17, CK-19 and bcl-2 (Rizzo et al, 2005). A further subpopulation of partially differentiated basal cells expressing CK-5, CK-14, and weak CK-18 is also documented (Rizzo et al, 2005). Expression patterns change as cells differentiate, resulting in an increase in CK-18 expression. The epithelial stem cells can also express CD133, a human analogue of prominin which is localised at membrane protrusions (Richardson et al, 2004). This stem cell population adheres rapidly to collagen as the cells also express high levels of $\alpha_{2} \beta_{1}$ integrin. The CD133+ population was shown to have high proliferative output, and high colony-forming efficiency, expressing CK-18, PSA, PAP, and AR negative (Richardson et al, 2004, Collins et al, 2005). A further cell surface antigen, prostate stem cell antigen (PSCA) has also been found to be expressed on basal cells (Bui and Reiter, 1999), although this population is mainly localized to the TP/A basal cell compartment rather than the stem cell compartment, and PSCA mRNA is also expressed in high grade PIN (Bui and Reiter, 1999). The breast cancer resistance protein (Huss et al, 2005) is a further putative stem cell marker. This too is predominantly expressed by TP/A basal cells and in BPH.

Significant populations of neuroendocrine cells, sometimes referred to as endocrine-paracrine cells also reside among the more abundant secretory epithelium in the normal prostate gland. These cells are found in the epithelium of the acini and in ducts of all parts of the gland. The major type of neuroendocrine cells contain serotonin, thyroid-stimulating hormone and chromogranin A. Neuroendocrine cells are terminally differentiated, post-mitotic cell types that are androgen-insensitive (Bui and Reiter, 1999) and can also express neuropeptide $Y$. Immunoreactivity to neuropeptide $Y$ was demonstrated in up to $75 \%$ of $\mathrm{CaP}$, suggesting a role in growth and progression of $\mathrm{CaP}$ (Ruscica et al, 2007). These differentiated cell populations can become more prominant in $\mathrm{CaP}$ with changes in number, histology and function (Nelson et al, 2007; Schalken and van Leenders, 2003) suggesting a regulatory role and demonstrating the plasticity of the differentiation program even in CaP. Mitogenic and oncogenic activities have also been demonstrated, for example expression of vascular endothelial growth factor (VEGF) leading to angiogenesis. 
Some neuroendocrine cells can also express somatostatin and even PSA (Nelson et al, 2007).

\subsection{Stromal epithelial interactions in the prostate}

The prostate is a complex tubulo-alveolar gland composed of an epithelial parenchyma embedded within a stromal tissue matrix. The stromal cells are responsible for direction of epithelial cell development, maintenance and differentiation. Stromal cells supply nutrients and growth factors, express adrenergic receptors, steroid receptors including AR, oestrogen receptor ( $E R \alpha$, $E R \beta$ ) and 5 - $\alpha$-reductase (required for conversion of testosterone to $5 \alpha-$ dihydrotestosterone; DHT). The three major cell types within stroma are:myofibroblasts, fibroblasts and smooth muscle cells within a connective tissue matrix. Myofibroblasts express procollagen 1, and are the main cell type within $\mathrm{CaP}$ reactive stroma (Ayala et al, 2003). Desmin, $\alpha$-actin, calponin, caldesmon, myosin, smoothelin and dystrophin are expressed by smooth muscle cells (Antonioli et al, 2007). Fibroblasts express vimentin and laminin (Micke and Östman, 2004, De Wever et al, 2003). Expression of these markers has been associated with CaP grade and survival (Ayala et al, 2003). Reactive CaP stroma is characterised by an increase in myofibroblasts and fibroblasts, with a significant decrease or complete loss of smooth muscle cells (Ayala et al, 2003),: see section 3.4 .

\subsection{Paracrine Growth factors}

Stromal cells produce several growth factors under the influence of androgens, some of these are discussed below. Androgens play a central role in the maintenance of prostate tissue and can regulate growth and differentiation of the different epithelial cell types, either directly or indirectly via the stroma. In the absence of ligand some of these growth factor pathways can still activate AR.

\section{2a Transforming growth factor $\beta$ (TGF $\beta$ )}

TGF $\beta$ exists in three different isoforms (1-3); all are potent inhibitors of epithelial cell growth and migration, but stimulate mesenchymal (stromal) cell proliferation and migration (Micke and Östman, 2004). Other actions include transdifferentiation of fibroblasts to myofibroblasts, and induction of extracellularmatrix components such as collagen, fibronectin, thrombospondin, osteopontin, osteonectin, elastin and protease inhibitors by cancer cells (Chung et al, 2003). These factors are especially important for the survival of metastatic cancer cells in bone. Most research in the prostate concerns TGF $\beta 1$. TGF $\beta$ synthesis is enhanced in CaP, but not in PIN or BPH (Zhao et al, 2005). As CaP progresses, the cancer cells become refractory to the growth inhibitory effects of TGF $\beta 1$. This is associated with a poor prognosis and similarly high expression of TGF $\beta 1$, or loss of TGF $\beta$-receptor, all are poor prognostic factors (Gerdes et al, 2004). TGF $\beta$ receptors- 1 and -2 mediate signalling. In CaP, TGF $\beta$ receptor- 2 is progressively 
lost due to promoter methylation leading to decreased growth inhibitory effects (Zhao et al, 2005). Treatment with demethylating agents, such as 5-aza-2'deoxycytidine, can restore expression of receptor- 2 and sensitivity to TGF $\beta$.

Complex cross-talk between androgen and TGF $\beta 1$ is well established in prostate stromal cells. TGF $\beta 1$ can transiently induce AR translocation from the nucleus to the cytoplasm and induce differentiation of fibroblasts to a myofibroblast phenotype, associated with cancer reactive stroma (Gerdes et al, 2004). Secreted TGF $\beta$ is bound to latent TGF $\beta$ binding protein-1. PSA is able to cleave this binding protein reducing release of TGF $\beta$ from extracellular matrix bound stores (Dallas et al, 2005). TGF $\beta 1$ can also directly stimulate secretion of basic fibroblast growth factor (bFGF/FGF2) in prostate stroma. This could lead to the antiproliferative effects of TGF $\beta 1$ being antagonized by FGF2 (Collins et al, 1996). Prostate-derived factor (PDF), is a member of the TGF $\beta$ superfamily and also acts as a paracrine and autocrine factor to induce proliferation of prostate cancer cells (Chen et al, 2007). Secretion of PDF was shown to induce proliferation and clonogenic growth of androgen receptor positive cells via the ERK1/2 signalling pathway (Chen et al, 2007).

TGF $\beta 2,3$ are predominantly expressed by prostate epithelial cells (Hisataki et al, 2004, Dallas et al, 2005) in contrast to TGF $\beta 1$ which is expressed by both stroma and epithelium. All three isoforms were able to induce expression of desmin and myosin - key stromal smooth muscle proteins, and significantly inhibited growth of prostate stromal cells (Hisataki et al, 2004). TGF $\beta 2$ has been shown to signal via the NF-kB pathway which, when activated can also block apoptosis, promoting tumour cell survival (Lu et al, 2004).

\section{2b Platelet Derived Growth factor (PDGF)}

Four PDGF polypeptide chains have been identified which can generate five dimeric PDGF isoforms. These are potent mitogens and chemoattractants for mesenchymal cells (Heldin et al, 2002). PDGF can stimulate TGF $\beta$ release and promote myofibroblast differentiation. Growth factors secreted in response to PDGF stimulation include insulin like growth factor (IGF-1), hepatocyte growth factor (HGF), FGF2, and endothelin-3. While there is no evidence for PDGF binding to AR, PDGF can stimulate both TGF $\beta 1$ and FGF2, which have been shown to bind AR (Gerdes et al, 2004, Kwabi-Addo et al, 2004). Small molecule inhibitors against TGF $\beta$ and PDGF are now in clinical trials and may represent a stromal targeted therapy (De Wever et al, 2003).

\section{2c Fibroblast Growth factors}

There are many FGF members, which function as growth regulatory proteins. FGF2, 8, 9, 10 and keratinocyte growth factor (KGF/FGF7) are the main stromal 
expressed proteins (Kwabi-Addo et al, 2004). FGF9 is a more potent mitogen for BPH epithelium and stroma than FGF2 or FGF7 (Giri et al, 1999). Prostate epithelial cells express multiple FGF receptors, FGFR-1 and FGFR-2 localised on basal cells, FGFR-4 on luminal cells, and FGFR-3 is also detected on epithelium. These receptors have multiple isoforms and can bind multiple FGF members (Kwabi-Addo et al, 2004, see Table 1 for a summary).

\begin{tabular}{|c|c|c|c|}
\hline Factor & Receptor & Actions & Reference \\
\hline FGF2 & FGFR-1,4 & $\begin{array}{l}\text { Proliferation, angiogenesis, } \\
\text { metastasis, autocrine, } \\
\text { paracrine, binds AR }\end{array}$ & Kwabi-Addo et al, (2004) \\
\hline $\begin{array}{l}\text { KGF/ } \\
\text { FGF7 }\end{array}$ & FGFR-2 & $\begin{array}{l}\text { Epithelial proliferation, } \\
\text { stromal differentiation } \\
\text { ductal braching } \\
\text { AR regulated, }\end{array}$ & $\begin{array}{l}\text { Huang et al, (2006), Heer } \\
\text { et al, (2005), } \\
\text { Grossfeld et al, (1998), } \\
\text { Peehl and Rubin, (1995) }\end{array}$ \\
\hline FGF8 & FGFR-1,4 & $\begin{array}{l}\text { Proliferation, correlation with } \\
\text { stage, prognostic factor, AR } \\
\text { binding region, } \mathrm{DHT} \text { induced }\end{array}$ & $\begin{array}{l}\text { Gnanapragasam et al, } \\
(2002)\end{array}$ \\
\hline FGF9 & FGFR-3 & $\begin{array}{l}\text { Mitogen on BPH epithelia, } \\
\text { low in CaP }\end{array}$ & Giri et al, (1999) \\
\hline FGF10 & FGFR-2 & $\begin{array}{l}\text { Paracrine regulator of } \\
\text { epithelia growth, no AR } \\
\text { regulation }\end{array}$ & $\begin{array}{l}\text { Thomson and Cunha, } \\
\text { (1999) }\end{array}$ \\
\hline
\end{tabular}

Table 1. Fibroblast growth factors and their effects on prostate stroma and epithelial cells.

\section{2d Epidermal Growth Factor (EGF)}

EGF has a 35\% sequence homology with transforming growth factor $\alpha$ (TGF $\alpha$ ) and can bind to the same trans-membrane receptor (EGFR/erbB1) in CaP. EGF and TGF $\alpha$ are both potent mitogens, and EGF can stimulate cell motility and invasion of CaP (Festuccia et al, 2005). Stromal expression of EGF has been shown, especially in osteogenic stroma where it may act as a chemoattractant for $\mathrm{CaP}$ invasion (Festuccia et al, 2005). The epidermal growth factor receptor-2 (ERBB2/Her-2) has significant homology with EGFR. ERBB2 gene amplification has been reported in breast and ovarian malignancies associated with poor prognosis, however, this is less apparent in CaP (Savinainen et al, 2002). Plasma membrane co-localization of AR and EGFR has been demonstrated in the PC-3 AR transfected CaP cell line and the androgen-sensitive LNCaP cell lines and co-immunoprecipitation confirmed an interaction (Bonaccorsi et al, 2004). This interaction may also be important for invasion and metastasis of $\mathrm{CaP}$. In the LNCaP cell line, both EGF and androgen could induce cell cycle regulated genes. Of those genes, $75 \%$ were the same suggesting EGF can stimulate androgen-regulated genes in the absence of androgen (Oosterhoff et al, 2005). 


\section{2e Hepatocyte Growth factor (HGF)}

HGF / scatter factor plays a critical role in the regulation of cell growth, motility, morphogenesis, and angiogenesis of tumours. Aberrant expression of HGF and its transmembrane tyrosine kinase receptor c-Met can often correlate with poor prognosis in cancer (Verras et al, 2007). In lung adenocarcinoma a significant relationship between myofibroblast c-Met expression and decreased patient survival was demonstrated, and similarly between high c-Met expression and stage 1A (lower stage) disease (Tokunou et al, 2001). A paracrine mechanism for HGF has been implicated in CaP progression as the c-Met receptor is expressed by both myofibroblasts and basal intermediate epithelial cells (Schalken and van Leenders, 2003). A further cell surface HGF binding protein, nucleolin has been shown in CaP (Tate et al, 2006). Nucleolin can bind heparinbound growth factors and can be upregulated during CaP progression (Tate et al, 2006). AR has been shown to repress c-Met expression in a ligand dependent manner via an Sp1 mediated transcription pathway (Verras et al, 2007). However, AR suppression (for example by SiRNA treatment or castration), can activate c-Met, leading to androgen independent growth in CaP (Maeda et al, 2006). C-Met expression is also regulated by other growth factors including TGF $\beta 1$ and PDGF in lung adenocarcinoma and FGF2 and PDGF can induce HGF expression and interact with the EGF receptor (Tokunou et al, 2001, Sirotnak et al, 2004).

\section{2f Insulin-like Growth factor (IGF1)}

IGF1 is produced mainly by prostatic stroma, whereas the receptor (IGF-R1) is expressed on basal and luminal epithelial cells (Ohlson et al, 2007). Receptor activation stimulates proliferation, repression of apoptosis and survival of $\mathrm{CaP}$ (Ohlson et al, 2007). Inhibition of AR can rapidly decrease IGF1 mRNA levels in normal stroma, but does not affect the low epithelial expression or expression within tumour stroma (Ohlson et al, 2007). IGF1 expression in epithelial cells was also increased in CaP and androgen induction of IGF1 synthesis has been shown. High IGF1 stores are found in bone, the main site for CaP metastasis (Ohlson et al, 2007). Danielpour (2005) showed that activation of IGF-R1 can block the induction of apoptosis by TGF $\beta 1$ in prostatic epithelial cells, suggesting a cross-talk between IGF1 and TGF $\beta 1$. Similarly IGF1, DHT and EGF each stimulated 20 genes common to all, suggesting IGF1 can stimulate androgen regulated genes in CaP epithelial cells (York et al, 2005).

\section{2g Caveolin 1}

Caveolin is a component of caveolae membranes which function as a scaffold protein and can associate with EGFR and insulin receptor (Lu et al, 2001). Expression has been detected in both epithelium and stroma and has been correlated with CaP progression (Lu et al, 2001), as is also the case in primary and metastatic breast cancer (Yang et al, 1998). Over expression of caveolin 1 
can inhibit ERBB2 expression and promote CaP progression. Co-localization of $A R$ with caveolin-rich membrane regions is androgen dependent and an interaction with the AR ligand-binding domain has been shown (Lu et al, 2001). $E R \alpha$ can also interact directly with caveolin 1, and since both AR and ER $\alpha$ are expressed by the stroma, this underlines the importance of caveolin 1 to prostate stroma (Freeman et al, 2005).

\section{2h Hypoxia-inducible factor (HIF $1 \alpha)$}

Increased expression of HIF1 $\alpha$ transcription factor has been correlated with diagnostic and prognostic factors in $\mathrm{CaP}$ and also in the presence of bone metastasis (Du et al, 2003). HIF1 $\alpha$ expression was also detected in high grade PIN (Kimbro and Simons, 2006). Tumour hypoxia, a regular feature as tumours increase in size, also results in up regulation of HIF1 $\alpha$ and VEGF. DHT stimulates both HIF1 $\alpha$ protein expression and VEGF production while EGF binding to EGFR can also increase HIF1 $\alpha$ expression (Kimbro and Simons, 2006).

\section{2i Interleukin 6 (IL-6)}

In $\mathrm{CaP}$, IL-6 induces divergent proliferative responses. IL-6 expression is also detected in PIN and BPH. IL-6 is secreted by prostate stroma and both stroma and epithelium express the IL-6 receptor which signals through the JAK/STAT pathway (Culig et al, 2002). IL-6 can activate AR in AR transfected cells, and IL-6 activation of AR is enhanced by the AR co-activator SRC-1 (Culig et al, 2004). IL-6 mediated growth arrest of the LNCaP prostate cancer cell line is lost during prolonged treatment possibly as a result of changes in signal transduction (Culig et al, 2002).

\section{2j Vascular endothelial growth factor (VEGF)}

Stromal myofibroblasts produce and secrete VEGF which acts to stimulate tumour angiogenesis and increased microvessel density in response to hypoxia and HIF1 $\alpha$ (Levine et al, 1998, Kimbro and Simons, 2006). Under these conditions DHT can further stimulate both VEGF production and HIF1 $\alpha$ protein expression (Kimbro and Simons, 2006). On foetal prostate fibroblasts DHT induced a two fold increase in the VEGF transcription rate and VEGF protein levels (Levine et al, 1998), suggesting VEGF is androgen regulated. VEGF expression is confined to stroma in $\mathrm{BPH}$, but in $\mathrm{CaP}$ both stroma and epithelium can express VEGF (Levine et al, 1998).

Further transcriptional targets for AR include protein kinase A, protein kinase C, and mitogen-activated protein kinase in the AR responsive LNCaP and 22RV1 $\mathrm{CaP}$ cell lines (Wang et al, 2006). The use of microarrays has influenced the discovery of potential androgen regulated genes in prostate stroma. Joesting et 
al, (2005) identified 119 genes differentially expressed between normal and $\mathrm{CaP}$ stroma including FGF8, IGF1 binding protein 5, a TGF $\beta 1$ induced protein and fibrillin 2. Similarly, Stuart et al, (2004) detected TGF $\beta 2$, fibulin 2 and connective tissue growth factor in BPH stroma. However, these studies did not isolate the AR positive fraction of stroma.

As discussed earlier (section 2), the cancer stem cell population resides in the basal compartment and is AR negative, whereas the luminal epithelial cells express AR. However, after androgen therapies for $\mathrm{CaP}$, the prostate epithelium becomes androgen refractive (section 1). The malignant epithelium and ARmediated growth is likely to be stimulated by stromally-derived paracrine factors (Chung et al, 2006). A number of the stromal factors discussed above have been shown to have effects on proliferation, motility and invasion of epithelial cells. These factors can be activated in the absence of androgens and lead to androgen independent growth of $\mathrm{CaP}$ (Maeda et al, 2006), suggesting that both the AR- and AR+ populations can be affected by paracrine stromal factors. The stem cell AR-population has the propensity for self-renewal and is undifferentiated compared to the AR+ population suggesting that stem cell fate could be influenced by androgen action on the stroma.

\subsection{Global gene expression analysis of $\mathrm{BPH}$ prostate stroma}

In our laboratory we have set out to further identify androgen-regulated factors produced by the stroma that may affect epithelial stem cell fate. The AR positive population in stroma expresses integrin $\alpha_{1} \beta_{1}$, which can be used to isolate the $A R$ fraction from stroma using magnetic cell sorting. Stroma was treated with DHT, RNA isolated, cRNA synthesized and subsequently hybridized to affymetrix GeneChip $₫$ cDNA microarrays (Berry et al, 2006). Analysis at two time points of DHT induction revealed 165 and 204 probes differentially expressed at $6 \mathrm{~h}$ and $14 \mathrm{~h}$ respectively. Within these lists were genes highly significant by expression, prostate specific, proliferation and differentiation associated, paracrine and autocrine factors, transcription factors, signalling effectors and putative androgen response genes. We have characterized some of these genes by RT-PCR, for protein expression and for functional AR binding. Stromal interaction molecule-1 (STIM1), a 90Kda cell surface transmemebrane glycoprotein is ubiquitously expressed by various human cell lines and tumours (Manji et al, 2000). STIM1 has been implicated in proliferation, migration and metastasis of cancer cells (Suyama et al, 2004). We have shown STIM1 protein is expressed by stroma and that expression is increased with DHT treatment. AR binding was determined using a chromatin immunoprecipitation assay which demonstrated binding to putative androgen response elements (ARE) within the STIM1 promoter.

Stromal-mediated effects influenced by AR signalling include epithelial proliferation, ductal branching morphogenesis, cytodifferentiation of epithelial 
cells, and maintenance of a growth-quiescent prostate. In contrast, the epithelial AR is required for expression of secretory proteins, such as PSA (Cunha et al, 2003). Stromal cells, together with extracellular matrix, provide a microenvironment that is pivotal for cancer cell growth, invasion and metastasis (Micke and Östman, 2004). In CaP there is a reduction in smooth muscle cells and fibroblasts with a further emergence of myofibroblasts, leading to what has been termed a cancer reactive stroma. Here, cells continue to express the structural proteins $\alpha$ actin, vimentin, fibronectin, and some integrins (Tuxhorn et al, 2002, Goo et al, 2005,). Reactive stroma has also been documented within PIN lesions, including: elevated vimentin expression, increased fibroblasts and the presence of myofibroblasts even though this is a pre-malignant state (Tuxhorn et al, 2002).

\subsection{Cancer reactive stroma}

Stromal cells are maintained during androgen ablation, unlike the luminal epithelial cell population that undergoes apoptosis (Setlur and Rubin, 2005). Levels of stromal, androgen-regulated growth factors, such as FGF and TGF $\beta$ decline. An altered stromal microenvironment always co-exists with $\mathrm{CaP}(\mathrm{De}$ Wever and Mareel, 2003). In desmoplastic tumours the stromal compartment can increase in size, reaching up to $90 \%$ (Brennen et al, 2006). Stromal cells alter the tumorigenic and metastatic potential of prostate epithelium and the characteristic reactive stroma emerges (Chung et al, 2003). There is also a loss of normal tissue architecture, nuclear atypia, genetic alterations, loss of tissue boundaries, and angiogenesis (Cunha et al, 2003). These altered microenvironments may allow a mechanism for a hormone-sensitive tumour to escape hormonal control, leading to an androgen-independent tumour and progression of disease. Tumour associated stroma is not restricted to $\mathrm{CaP}$, it has also been documented in breast cancer, characterized by high expression of metalloproteinase-2, fibroblast activation protein (FAP), stromeolysin 3 , tenascin, and hyaluronan expression (Grossfeld et al, 1998, Tuxhorn et al, 2002). The stromal microenvironment can also regulate $\mathrm{E}$-cadherin expression in the epithelium, which is important for cell adhesion and associates with $\beta$ catenin which is involved in Wnt signalling (Etheridge et al, 2004).

E-cadherin down regulation leads to decreased adherence of cells, and may be a precursor for both increased cell motility and metastatic spread, resulting in a tumour which has escaped hormonal control, leading ultimately to androgenindependent disease. FAP is a cell surface glycoprotein with protease activity, whose expression is confined to tumour reactive stroma. FAP is expressed not only in CaP (Tuxhorn et al, 2002), but was also found to be expressed in more than $90 \%$ of lung, breast and colon carcinomas (Mersmann et al, 2001). FAP may also represent a pathway for a stromal targeted therapy by selective activation of a prodrug consisting of a FAP specific peptide substrate coupled to a potent cytotoxin to target FAP positive tumour stromal cells (Brennen et al, 2006). 
Usually the stroma is genetically stable and less likely to undergo genetic changes which can result in chemoresistance (De Wever et al, 2003). However, tumour-suppressor gene mutations have been documented within stroma and can affect tumour progression (Hill et al, 2005). In a mouse model of CaP, inhibition of the retinoblastoma gene function induced a paracrine $p 53$ response and suppression of associated stromal cells and led to a proliferative stroma with p53 loss (Hill et al, 2005). Loss of heterozygosity (LOH) at several loci has been demonstrated in up to $75 \%$ of mammary stroma samples. The most frequent alterations were at chromosome 17q, 16q, 3p, and 11q (Monifar et al, 2000). Bladder stromal samples also showed LOH at 17p, 3p and 9q (Paterson et al, 2003). Stromal LOH was detected in up to $78 \%$ of samples, in at least one of three markers examined. Further, evidence for genetic instability in microdissected human prostate stroma at $8 p$ has been shown (Macintosh et al, 1998), where LOH was found in $33 \%$ of tumour associated stromal samples. Another study evaluated gene methylation of glutathione S-transferease 1 (GSTP1), retinoic acid recetor $\beta 2$ (RAR $\beta 1$ ) and CD44, three genes shown to be methylated in CaP epithelium. Methylation of GSTP1 and RAR $\beta 2$ was documented in $80 \%$ of stromal samples although only five samples were analysed in this study (Hanson et al, 2006). This suggests a therapy that can also target the stromal compartment to prevent acceleration of tumourigenesis would be most useful (Hill et al, 2005). High levels of epithelial AR expression, or low stromal AR expression correlated with recurrence of CaP or earlier relapse of disease (Ricciardelli et al, 2005). AR amplification does not necessarily lead to increased AR expression, but can affect PSA expression and patient survival (Setlur and Rubin, 2005, Edwards et al, 2003). AR amplification maybe a mechanism whereby $\mathrm{CaP}$ is sensitive to reduced androgen levels after androgen ablation therapy (Heinlein and Chang, 2004).

\subsection{ANDROGEN RECEPTOR SIGNALLING PATHWAY.}

The androgen receptor signalling pathway is critical to the development and progression of $\mathrm{CaP}$ and $\mathrm{BPH}$ (Holzbeierlein et al, 2004). The AR mediates male sexual differentiation during development, sperm production from puberty, and maintenance of normal prostate (Heinlein and Chang, 2004). The prostate stem cells do not express the AR, but the prostate stroma does, hence the importance of prostate stroma in AR signalling. The AR has three main domains, a Cterminal ligand binding domain (LBD), an N-terminal transcriptional activation domain and a central DNA binding domain consisting of two zinc finger motifs and a hinge domain. Binding of androgen induces a conformational change, receptor dimerization, and nuclear translocation of the hormone-receptor complex (Setlur and Rubin, 2005). This complex binds to specific androgen response elements (ARE) in the upstream promoter of target genes and along with several co-activator proteins (co-activators and co-repressors), leads to transcriptional activation and modulation of an RNA polymerase II transcription complex that can regulate expression of androgen-regulated genes (Shang et al, 
2002; Cano et al, 2007). ARE motifs are 15bp palindromic units with a high degree of homology to the consensus ARE motif AGAACAnnnTGTTCT and are found in a wide range of differing genes, some of which have been associated with prostate disease (Holzerbeierlein et al, 2004, York et al, 2005). Since this $A R E$ unit can bind $A R$, an ARE in the gene promoter sequence suggests a potential direct mechanism of action on AR binding. The best characterised androgen response elements are those in the 5' PSA promoter/enhancer. Two ARE are found in the PSA proximal promoter, and a further ARE in the enhancer region of the PSA gene (Shang et al, 2002, Riegman et al, 1991).

Experiments using AR chromatin immunoprecipitation coupled with DNA microarrays showed that most AR binding sites were far from the transcriptional start site of androgen responsive genes (Wang et al, 2007). In two studies only $5-10 \%$ of potential AR binding sites had a typical $15 \mathrm{bp}$ canonical ARE, $16-22 \%$ had no ARE motif and a further $68-79 \%$ had a non-canonical $15 \mathrm{bp}$ or $6 \mathrm{bp}$ half site ARE. These non-canonical sites, some of which were frequently repeated, are thought to be more important for enhancer promoter function (Wang et al, 2007, Massie et al, 2007). Many of these binding sites were located downstream from the start of transcription, in intronic regions or a long way upstream from the transcription start site (Takayama et al, 2007). Hence, ARE provide little evidence of selective pressure on the promoter, but may allow for combinatorial transcription factor regulation (Bolton et al, 2007).

Enhancer ARE can often be low affinity for AR, non-canonical ARE can be found in the enhancer region as compared to the promoter ARE. However, Kang et al, (2004) found that 200X more AR was loaded on to the enhancer compared to the promoter ARE of the PSA gene, but both promoter and enhancer ARE were needed for maximal activity. Conversely, more RNA polymerase II transcription factor was recruited to the promoter ARE. Differential histone acetylation modifications were noted between the promoter and enhancer ARE of PSA with the promoter ARE dependent on RNA polymerase II phosphorylation (Kang et al, 2004, Wang et al, 2005).

The AR can also be modulated by oestrogen, although oestrogen and androgen do not function synergistically but exert their effects independently. However, one steroid can increase sensitivity for the other (Collins et al, 1994). For example oestrogen can stimulate the proliferation of stromal cells, although the number of binding sites for the synthetic oestrogen oestradiol-17 $\beta$ was found to be much lower than the number of binding sites for androgen (Collins et al, 1994).

To further modulate AR activity, co-activators SRC-1, TIF2, pCIP recruit histone acetyltransferases CBP and pCAF, and the methyl-transferases CARM1 and PRMT to modify chromatin structure of androgen-regulated promoters. These modulators can enhance transcription, while co-repressors SMRT and NCoR interact with histone deacetylases to repress transcription. The transcription 
factor TRAP220 was found to be indispensable for AR mediated transcription. However, any loss of SRC-1 could be overcome by GRIP1 or AIB1 (Wang et al, 2005) suggesting co-operation of numerous DNA-binding factors and coregulators are required.

The stromal AR in CaP stroma was found to be associated with the co-repressor SMRT and AR mediated transcriptional activity was reduced compared to that of BPH stroma (Cano et al, 2007). In reactive stroma, the prostate stroma-specific AR coactivator Hic-5/ARA55 has been found (Heitzer and DeFranco, 2007). This may play a role in regulation of FGF7 growth factor expression and has been shown to influence FGF7 expression (Heitzer and DeFranco, 2007).

A variety of co-activators are reported to be up-regulated in $\mathrm{CaP}$ including SRC-1, TIF2, ARA70, nmt55, Tip60 (Setlur and Rubin, 2005, Halkidou et al, 2003, Culig et al, 2004). This incease may lead to an increase in AR regulated gene expression, stability, nuclear translocation and increased AR transcription (Setlur and Rubin, 2005). But there is yet little evidence to show these cofactors impact on pathology and survival ahead of factors like AR amplification and PSA expression.

\subsection{ANDROGEN RECEPTOR MUTATIONS.}

Numerous mutations have been documented within the $A R$ (Linja and Visakorpi, 2004). One of the best documented is that in the cell line LNCaP, the common cell line used in most prostate studies. A mutation, T877A (threonine to alanine) in the LBD allows the receptor to be activated by other steroid hormones including oestradiol, progesterone and the antiandrogen flutamide (Veldscholte et al, 1990). AR point mutations can occur spontaneously, for example: in the transgenic adenocarcinoma mouse prostate (TRAMP) model. This model has a probasin promoter driven SV40 T antigen transgene which gives rise to a tumour within the dorsolateral/peripheral zone of the mouse prostate (Gingrich et al, 1996). The tumour can metastasise to lymph node, lung or bone in selected mouse colonies. Mutations can be selected by androgen removal, or by treatment with antiandrogens (Grossmann et al, 2001, Linja and Visakorpi, 2004). Genetic polymorphisms in the AR gene may play a direct role in clinical outcome of $\mathrm{CaP}$. For example short CAG repeats have been correlated with increased risk for $\mathrm{CaP}$, particularly at an early age. Such polymorphisms may also account for differences in the higher mortality for $\mathrm{CaP}$ noted amongst different racial groups (Linja and Visakorpi, 2004), although this remains controversial. In BPH the number of CAG repeats in the PSA and AR genes was not related to clinical outcome, in contrast to CaP (Schatzl et al, 2002). $A R$ mutations are also common as prostate cancer progresses. These mutations are often seen in the hinge region or LBD resulting in broader ligand specificity and can allow antagonist AR activation. Over two hundred different mutations have been reported, these are not exclusive to $\mathrm{CaP}$, and many germ line mutations including short sequence repeats are reported. Some of these may confer an 
increased risk for $\mathrm{CaP}$ in later life though, or earlier age of disease onset although evidence is limited (Linja and Visakorpi, 2004). No significant changes have been seen in the $A R$ gene structure or expression in stroma associated with hormone refractory cancer although; in the presence of anti-androgens the AR expressing stroma can be less evident. The mechanism of restoration of glandular architecture and differentiation is closely dependent on stromal influences after restoration of androgen levels. This would require retention of some residual androgen responsive stromal cells, or the activation of alternative growth factor pathways.

\subsection{Conclusions}

Stromal cells, with the capacity to respond to androgens, form an important and understudied cellular compartment of human prostate. The ability of a multitude of growth factors, secreted by stroma to enhance the survival, motility and growth rates of different cells in the epithelial compartment should offer new directions for therapeutic development in the future. 


\section{Acknowledgements}

We acknowledge Yorkshire Cancer Research for a project grant to fund the stromal-epithelial interaction project. We acknowledge Mr Michael J Stower, Department of Urology, York Hospitals NHS Trust, York, UK for provision of surgical prostate samples. 


\section{REFERENCES.}

Antonioli, E., Cardoso, A.B., Carvalho, H.F., 2007. Effects of long-term castration on the smooth muscle cell phenotype of the rat ventral prostate.

J Androl 28, 777-783.

Ayala, G., Tuxhorn, J.A., Wheeler, T.M., Frolov, A., Scardino, P.T., Ohori, M., Wheeler, M., Spitler, J., Rowley, D.R., 2003. Reactive stroma as a predictor of biochemical-free recurrence in prostate cancer.

Clinical Cancer Res. 9, 4792-4801.

Berry, P.A., Maitland, N.J., Collins, A.T., 2006. The role of androgen signalling in the regulation of human prostate epithelial stem cell differentiation. Prostate Cancer and Prostatic Diseases 9, 360-361.

Bolton, E.C., So, A.Y., Chiavorapol, C., Haqq, C.M., Li, H., Yamamoto, K.R., 2007. Cell-and gene-specific regulation of primary target genes by the androgen receptor. Genes and Development 21, 2005-2017.

Bonaccorsi, L., Muratori, M., Carloni, V., Marchiani, S., Formigli, L., Forti, G., Baldi, E., 2004. The androgen receptor associates with the epidermal growth factor receptor in androgen-sensitive prostate cancer cells. Steroids 69, 549-552. Bonkhoff, H., Remberger, K.D., 1996. Differentiation pathways and histogenetic aspects of normal and abnormal prostatc growth: a stem cell model.

Prostate 28, 98-106.

Brennen, N., Aggarwal, S., Cole, T., Denmeade, S.R., 2006. Fibroblast activation protein: Targeting the reactive tumor stroma. AACR Innovation in prostate cancer research meeting. December, San Francisco.

Bui, M., Reiter, R.E., 1999. Stem cell genes in androgen-independent prostate cancer. Cancer Metastasis Reviews 17,391-399.

Cancer Research UK website/news \& resources/UK cancer incidence statistics.

Cano, P., Godoy, A., Escamilla, R., Dhir, R., Onate, S.A., 2007. Stromalepithelial cell interactions and androgen receptor-coregulator recruitment is altered in the tissue microenvironment of prostate cancer.

Cancer Res 67, 511-519.

Chen, S-J., Karan, D., Johansson, S.L., Lin, F-F., Zeckser, J., Singh, A.P., Batra, S.K., Lin, M-F. 2007. Prostate-derived factor as a paracrine and autocrine factor for the proliferation of androgen receptor-positive human prostate cancer cells. The Prostate 67, 557-571.

Cho, K.S., Kim, J., Choi, Y.D., Kim, J.H., Hong, S.J., 2007. The overlooked cause of benign prostatic hyperplasia: prostatic urethral angulation. Medical Hypotheses 70, 532-535.

Chung, L.W.K., Hsieh, C-L., Law, A., Sung, S-Y., Gardner, T.A, Egawa, M., Matsubara, S., Zhau, H.E., 2003. New targets for therapy in prostate cancer: modulation of stromal-epithelial interactions. Urology 62, 44-54.

Chung, L.W.K., Huang, W-C., Sung, S-Y., Wu, D., Odero-Marah, V., Nomura, T., Shigemura, K., Miyagi, T., Seo, S., Shi, C., Molitierno, J., Elmore, J., Anderson, C., Isotani, S., Edlund, M., Hsieh, C-L., Wang, R., Shehata, B., Zhau, H.E., 2006. Stromal-epithelial interaction in prostate cancer progression. Clinical Genitourinary Cancer 5, 162-170. 
Collins, A.T., Zhiming, B., Gilmore, K., Neal, D.E., 1994. Androgen and oestrogen responsiveness of stromal cells derived from the human hyperplastic prostate: oestrogen regulation of the androgen receptor.

J Endocrinology 143, 269-277.

Collins, A.T., Robinson, E.J., Neal, D.E., 1996. Benign prostatic stromal cells are regulated by basic fibroblast growth factor and transforming growth factor- $\beta 1$. J Endocrinology 151, 315-322.

Collins, A.T., Berry, P.A., Hyde, C., Stower, M.J., Maitland, N.J., 2005.

Prospective identification of tumorigenic prostate cancer stem cells.

Cancer Res. 65, 10946-10951.

Collins, A.T., Maitland, N.J., 2006. Prostate cancer stem cells.

Eur J Cancer. 42, 1213-1218.

Culig, Z., Bartsch, G., Hobisch, A., 2002. Interleukin-6 regulates androgen

receptor activity and prostate cancer cell growth. Molecular and Cellular

Endocrinol 197, 231-238.

Culig,Z., Comuzzi, B., Steiner, H., Bartsch, G., Hobisch, A., 2004. Expression and function of androgen receptor coactivators in prostate cancer. J Steroid Biochemistry \& Molecular Biol. 92, 265-271.

Cunha, G.R., Hayward, S.W., Wang, Y.Z., Ricke, W.A., 2003. Role of the stromal microenvironment in carcinogenesis of the prostate. Int J Cancer 107, 1-10.

Dallas, S.L., Zhao, S., Cramer, S.D., Chen, Z., Peehl, D.M., Bonewald, L.F., 2004. Preferential production of latent transforming growth factor $\beta-2$ by primary prostatic epithelial cells and its activation by prostate-specific antigen. J. Cellular physiology 202, 361-370.

Danielpour, D., 2005. Functions and regulation of transforming growth factor-beta (TGF- $\beta$ ) in the prostate. EJCa 41, 846-857.

De Wever, O. Mareel, M., 2003. Role of tissue stroma in cancer cell invasion.

J. Pathol 200, 429-447.

Du, Z., Fujiyama, C., Chen, Y., Masaki, Z., 2003. Expression of hypoxia-inducible factor 1 alpha in human normal, benign, and malignant prostate tissue. Chin Med $\mathrm{J}$ (Engl) 116, 1936-1939.

Edwards, J., Krishna, N.S., Grigor, K.M., Bartlett, J.M., 2003. Androgen receptor gene amplification and protein expression in hormone refractory prostate cancer. Br J Cancer 89, 552-556.

Etheridge, S.L., Spencer, G.J., Heath, D.J., Genever, P.G., 2004. Expression profiling and functional analysis of Wnt signaling mechanisms in mesenchymal stem cells. Stem cells 22, 849-860.

Festuccia, C., Angelucci, A., Luca Gravina, G., Biordi, L., Millimaggi, D., Muzi, P., Vicentini, C., Bologna, M., 2005. Epidermal growth factor modulates prostate cancer cell invasiveness regulating urokinase-type plasminogen activator activity. Thromb Haemost 93, 964-975.

Freeman, M.R., Cinar, B., Lu, M.L., 2005. Membrane rafts as potential sites of nongenomic hormonal signaling in prostate cancer. Trends in Endocrin Metabolism 16, 273-279. 
Gerdes, M.J., Larsen, M., Dang, T.D., Ressler, S.J., Tuxhorn, J.A., Rowley, D.R., 2004. Regulation of rat prostate stromal cell myodifferentiation by androgen and TGF- $\beta 1$. The Prostate 58, 299-307.

Gingrich, J.R., Barrios, R.J., Morton, R.A., Boyce, B.F., DeMayo, F.J., Finegold, M.J., Angelopoulou, R., Rosen, J.M., Greenberg, N.M., 1996. Metastatic prostate cancer in a transgenic mouse. Cancer Res. 56, 4096-4102.

Giri, D., Ropiquet, F., Ittmann, M., 1999 FGF9 is an autocrine and paracrine prostatic growth factor expressed by prostatic stromal cells.

J. Cell Physiol. 180, 53-60.

Gnanapragasam, V.J., Robson, C.N., Neal, D.E., Leung, H.Y., 2002. Regulation of FGF8 expression by the androgen receptor in human prostate cancer.

Oncogene 21, 5069-5080.

Goo, Y.A., Goodlett, D.R., Pascal, L.E., Worthington, K.D., Vessella, R.L., True, L.D., Liu, A.Y., 2005. Stromal mesenchyme cell genes of the human prostate and bladder. BMC Urology 5, 17-28.

Grossfeld, G.D., Hayward, S.W., Tlsty, T.D., Cunha, G.R., 1998. The role of stroma in prostatic carcinogenesis. Endocrine-Related Cancer 5, 253-270.

Grossmann, M.E., Huang, H., Tindall, D.J., 2001. Androgen receptor signaling in androgen-refractory prostate cancer. J Natl Cancer Inst 93, 1687-97.

Halkidou, K., Gnanapragasam, V.J., Mehta, P.B., Logan, I.R., Brady, M.E., Cook, S., Leung, H.Y., Neal, D.E., Robson, C.N. (2003) Expression of Tip60, an androgen receptor coactivator, and its role in prostate cancer development. Oncogene 22, 2466-2477.

Hanson, J.A., Gillespie, J.W., Grover, A., Tangrea, M.A., Chuaqui, R.F., EmmertBuck, M.R., Tangrea, J.A., Libutti, S.K., Linehan, M., Woodson, K.G., 2006. Gene promoter methylation in prostate tumor-associated stromal cells. J Natl Cancer Inst 98, 255-261.

Heer, R., Collins, A.T., Robson, C.N., Shenton, B.K., Leung, H.Y., 2006. KGF suppresses $\alpha_{2} \beta_{1}$ integrin function and promotes differentiation of the transient amplifying population in human prostatic epithelium.

J Cell Science 119, 1416-1424.

Heinlein, C.A., Chang, C., 2004. Androgen receptor in prostate cancer.

Endocrine Reviews 25, 276-308.

Heitzer, M.D., DeFranco, D.B., 2007. Hic-5/ARA55 a prostate stroma-specific AR coactivator. Steroids 72, 218-220.

Heldin, C-H., Eriksson, U., Östman, A., 2002. New members of the plateletderived growth factor family of mitogens.

Archives Biochem Biophys 398, 284-290.

Hill, R., Song, Y., Cardiff, R.D., van Dyke, T., 2005. Selective evolution of stromal mesenchyme with p53 loss in response to epithelial tumourigenesis.

Cell 123, 1001-1011.

Holzbeierlein, J., Lal, P., LaTulippe, E., Smith, A., Satagopan, J., Zhang, L., Ryan, C., Smith, S., Scher, H., Scardino, P., Reuter, V., Gerald, W.L., 2004. Gene expression analysis of human prostate carcinoma during hormonal therapy identifies androgen-responsive genes and mechanisms of therapy resistance. Am J Pathol 164, 217-227. 
Huang, Y-W., Wang, L-S., Chang, H-L., Ye, W., Shu, S., Sugimoto, Y., Lin, Y.C., 2006. Effect of keratinocyte growth factor on cell viability in primary cultured human prostate cancer stromal cells. Journal of steroid Biochemistry \& Molecular Biology 100, 24-33.

Huss, W.J., Gray, D.R., Greenberg, N.M., Mohler, J.L., Smith, G.J., 2005. Breast cancer resistance protein-mediated efflux of androgen in putative benign and malignant prostate stem cells. Cancer Res. 65, 6640-6650.

Joesting, M.S., Perrin, S., Elenbaas, B., Fawell, S.E., Rubin, J.S., Franco, O.E., Hayward, S.W., Cunha, G.R., Marker, P.C., 2005. Identification of SFRP1 as a candidate mediator of stromal-to-epithelial signaling in prostate cancer. Cancer Res. 65, 10423-10430.

Kang, Z., Jänne, O.A., Palvimo, J.J., 2004. Coregulator recruitment and histone modifications in transcriptional regulation by the androgen receptor. Molecular Endocrinol. 18, 2633-2648.

Kimbro, K.S., Simons, J.W., 2006. Hypoxia-inducible factor-1 in human breast and prostate cancer. Endocrine-Related Cancer 13, 739-749.

Kwabi-Addo, B., Ozen, M., Ittmann, M., 2004. The role of fibroblast growth factors and their receptors in prostate cancer.

Endocrine-Related Cancer 11, 709-724.

Levine, A.C., Liu, X-H., Greenberg, P.D., Eliashvili, M., Schiff, J.D., Aaronson, S.A., Holland, J.F., Kirschenbaum, A., 1998. Androgens induce the expression of vascular endothelial growth factor in human fetal prostatic fibroblasts.

Endocrinology 139, 4672-4678.

Linja, M.J., Visakorpi, T., 2004. Alterations of androgen receptor in prostate cancer. J. Steroid Biochem \& Molecular Biol. 92, 255-264.

Lu, M.L., Schneider, M.C., Zheng, Y., Zhang, X., Richie, J.P., 2001. Caveolin-1 interacts with androgen receptor. J Biological Chemistry 276, 13442-13451. Macintosh, C.A., Stower, M.J., Reid, N., Maitland, N.J., 1998. Precise microdissection of human prostate cancers reveals genotypic heterogeneity. Cancer Res. 58, 23-28.

Maeda, A., Nakashiro, K-I., Hara, S., Sasaki, T., Miwa, Y., Tanji, N., Yokoyama, M., Hamakawa, H., Oyasu, R., 2006. Inactivation of AR activates HGF/c-Met system in human prostatic carcinoma cells. Biochem Biophys Res Commun. 347, 1158-1165.

Manji, S.S., Parker, N.J., Williams, R.T., van Stekelenberg, L., Pearson, R.B., Dziadek, M., Smith, P.J., 2000. STIM1: a novel phosphoprotein located at the cell surface. Biochim Biophys Acta. 1481, 147-155.

Massie, C.E., Adryan, B., Barbosa-Morais, N.L., Lynch, A.G., Tran, M.G., Neal, D.E., Mills, I.G., 2007. New androgen receptor genomic targets show an interaction with the ETS1 transcription factor. EMBO reports 8, 871-878. Mersmann, M., Schmidt, A., Rippmann, J.F., Wüest, T., Brocks, B., Rettig, W.J., Garin-Chesa, P., Pfizenmaier, K., Moosmayer D., 2001. Human antibody derivatives against the fibroblast activation protein for tumour stroma targeting of carcinomas. Int. J. Cancer 92, 240-248. 
Micke, P., Östman, A., 2004. Tumour-stroma interaction: cancer-associated fibroblasts as novel targets in anti-cancer therapy?

Lung cancer 45S2, S163-S175.

Nelson, E.C., Cambio, A.J. Yang, J.C. Ok, J-H., Lara Jr, P.N., Evans, C.P., 2007. Clinical implications of neuroendocrine differentiation in prostate cancer. Prostate Cancer and Prostatic Diseases 10, 6-14.

Ohlson, N., Bergh, A., Stattin, P., Wikström, P., 2007. Castration-induced epithelial cell death in human prostate tissue is related to locally reduced IGF-1 levels. The Prostate 67, 32-40.

Oosterhoff, J.K., Grootegoed, J.A., Blok, L.J., 2005. Expression profiling of androgen-dependent and -independent LNCaP cells: EGF versus androgen signalling. Endocrine-Related Cancer 12, 135-148.

Paterson, R.F., Ulbright, T.M., MacLennan, G.T., Zhang, S., Pan, C-X., Sweeney, C.J., Moore, C.R., Foster, R.S., Koch, M.O., Eble, J.N., Cheng, L., 2003. Molecular genetic alterations in the laser-capture-microdissected stroma adjacent to bladder carcinoma. Cancer 98, 1830-1836.

Peehl, D.M., Rubin, J.S., 1995. Keratinocyte growth factor: an androgenregulated mediator of stromal-epithelial interactions in the prostate.

World J Urol 13, 312-317.

Ricciardelli, C., Choong, C.S., Buchanan, G., Vivekanandan, S., Neufing, P., Stahl, J., Marshall, V.R., Horsfall, D.J., Tilley, W.D., 2005. Androgen receptor levels in prostate cancer epithelial and peritumoral stromal cells identify nonorgan confined disease. The Prostate 63, 19-28.

Richardson, G.D., Robson, C.N., Lang, S.H., Neal, D.E., Maitland, N.J., Collins, A.T., 2004. CD133, a novel marker for human prostatic epithelial stem cells.

J. Cell Sci. 117, 3539-3545.

Riegman, P.H.J., Vlietstra, R.J., van der Korput, J.A.G.M., Brinkmann, A.O., Trapman, J., 1991. The Promoter of the prostate-specific antigen gene contains a functional androgen responsive element. Molecular Endocrin 5, 1921-1930. Rizzo, S., Attard, G., Hudson D.L., 2005. Prostate epithelial stem cells. Cell Prolif 38, 363-374.

Ruscica, M., Dozio, E., Motta, M., Magni, P., 2007. Role of neuropeptide Y and its receptors in the progression of endocrine-related cancer.

Peptides 28, 426-434.

Savinainen, K.J., Saramäki, O.R., Linja, M.J., Bratt, O., Tammela, T.L.J., Isola, J.J., Visakorpi, T., 2002. Expression and gene copy number analysis of ERBB2 oncogene in prostate cancer. Am J Pathol 160, 339-345.

Schalken, J.A., van Leenders, G., 2003. Cellular and molecular biology of the prostate: stem cell biology. Urology 62(5 Suppl 1), 11-20.

Schatzl, G., Madersbacher, S., Gsur, A., Preyer, M., Haidinger, G., Haitel, A., Vutuc, C., Micksche, M. Marberger, M., 2002. Association of polymorphisms within androgen receptor, $5 \alpha$-reductase, and PSA genes with prostate volume, clinical parameters, and endocrine status in elderly men.

The Prostate 52, 130-138.

Setlur, S.R., Rubin, M.A., 2005. Current thoughts on the role of the androgen receptor and prostate cancer progression. Adv Anat Pathol 12, 265-270. 
Shang, Y., Myers, M. Brown, M., 2002. Formation of the androgen receptor transcription complex. Molecular Cell 9, 601-610.

Sirotnak, F.M., She, Y., Khokhar, N.Z., Hayes, P., Gerald, W., Scher, H.I., 2004. Microaaray analysis of prostate cancer progression to reduced androgen dependence: Studies in unique models contrasts early and late molecular events. Mol. Carcinogenesis 41, 150-163.

Stuart, R.O., Wachsman, W., Berry, C.C., Wang-Rodriguez, J., Wasserman, L., Klacansky, I., Masys, D., Arden, K., Goodison, S., McClelland, M., Wang, Y., Sawyers, A., Kalcheva, I., Tarin, D., Mercola, D., 2004. In silico dissection of celltype-associated patterns of gene expression in prostate cancer.

PNAS 101, 615-620.

Suyama, E., Wadhwa, R., Kaur, K., Miyagishi, M., Kaul, S.C., Kawasaki, H., Takayama, K., Kaneshiro, K., Tsutsumi, S., Horie-Inoue, K., Ikeda, K., Urano, T., Ijichi, N., Ouchi, Y., Shirahige, K., Aburatani, H., Inoue, S., 2007 Identification of novel androgen response genes in prostate cancer cells by coupling chromatin immunoprecipitation and genomic microarray analysis.

Oncogene 26, 4453-4463.

Tate, A., Isotani, S., Bradley, M.J., Sikes, R.A., Davis, R., Chung, L.W.K., Edlund, M., 2006. Met-independent hepatocyte growth factor-mediated regulation of cell adhesion in human prostate cancer cells. BMC Cancer 6, 197-212. Thomson, A.A., Cunha, G.R., 1999. Prostatic growth and development are regulated by FGF10. Development 126, 3693-3701.

Tokunou, M., Niki, T., Eguchi, K., Iba, S., Tsuda, H., Yamada, T., Matsuno, Y., Kondo, T., Saitoh, Y., Imamura, H. Hirohashi, S., 2001. c-MET expression in myofibroblasts- Role in autocrine activation and prognostic significance in lung adenocarcinoma. Am J Path 158, 1451-1463.

Tuxhorn, J.A., Ayala, G.E., Smith, M.J., Smith, V.C., Dang, T.D., Rowley, D.R., 2002. Reactive stroma in human prostate cancer: induction of myofibroblast phenotype and extracellular matrix remodeling.

Clin Cancer Research 8, 2912-23.

Veldscholte, J., Ris-Stalpers, C., Kuiper, G.G., Jenster, G., Berrevoets, C., Claassen, E., van Rooij, H.C., Trapman, J., Brinkmann, A.O., Mulder, E., 1990. A mutation in the ligand binding domain of the androgen receptor of human LNCaP cells affects steroid binding characteristics and response to antiandrogens. Biochem Biophys Res Commun. 173, 534-540.

Verras, M., Lee, J., Xue, H., Li, T-H., Wang, Y., Sun, Z., 2007. The androgen receptor negatively regulates the expression of c-Met: Implicatuions for a novel mechanism of prostate cancer progression. Cancer Res. 67, 967-975.

Wang, G., Jones, S.J.M., Marra, M.A., Sadar, M.D., 2006. Identification of genes targeted by the androgen and PKA signaling pathways in prostate cancer cells. Oncogene 25, 7311-7323.

Wang, Q., Carroll, J.S., Brown, M., 2005. Spatial and temporal recruitment of androgen receptor and its coactivators involves chromosomal looping and polymerase tracking. Molecular Cell 19, 631-642. 
Wang, Q., Li, W., Liu, X.S., Carroll, J.S., Jänne, O.A., Krasnickas Keeton, E., Chinnaiyan, A.M., Pienta, K.J., Brown, M., 2007. A hierarchical network of transcription factors governs androgen receptor-dependent prostate cancer growth. Molecular Cell 27, 380-392.

Yang, G., Truong, L.D., Timme, T.L., Ren, C., Wheeler, T.M., Park, S.H., Nasu, Y., Bangma, C.H., Kattan, M.W., Scardino, P.T., Thompson, T.C., 1998. Elevated expression of caveolin is associated with prostate and breast cancer. Clinical Cancer Research 4, 1873-1880.

York, T.P., Plymate, S.R., Nelson, P.S., Eaves, L.J., Webb, H.D., Ware, J.L., 2005. cDNA microarray analysis identifies genes induced in common by peptide growth factors and androgen in human prostate epithelial cells. Molecular Carcinogenesis 44, 242-251.

Zhao, H., Shiina, H., Greene, K.L., Li, L-C., Tanaka, Y., Kishi, H., Igawa, M., Kane, C.J., Carroll, P., Dahiya, R., 2005. CpG methylation at promoter site-140 inactivates TGF $\beta 2$ receptor gene in prostate cancer. Cancer 104, 44-52. 


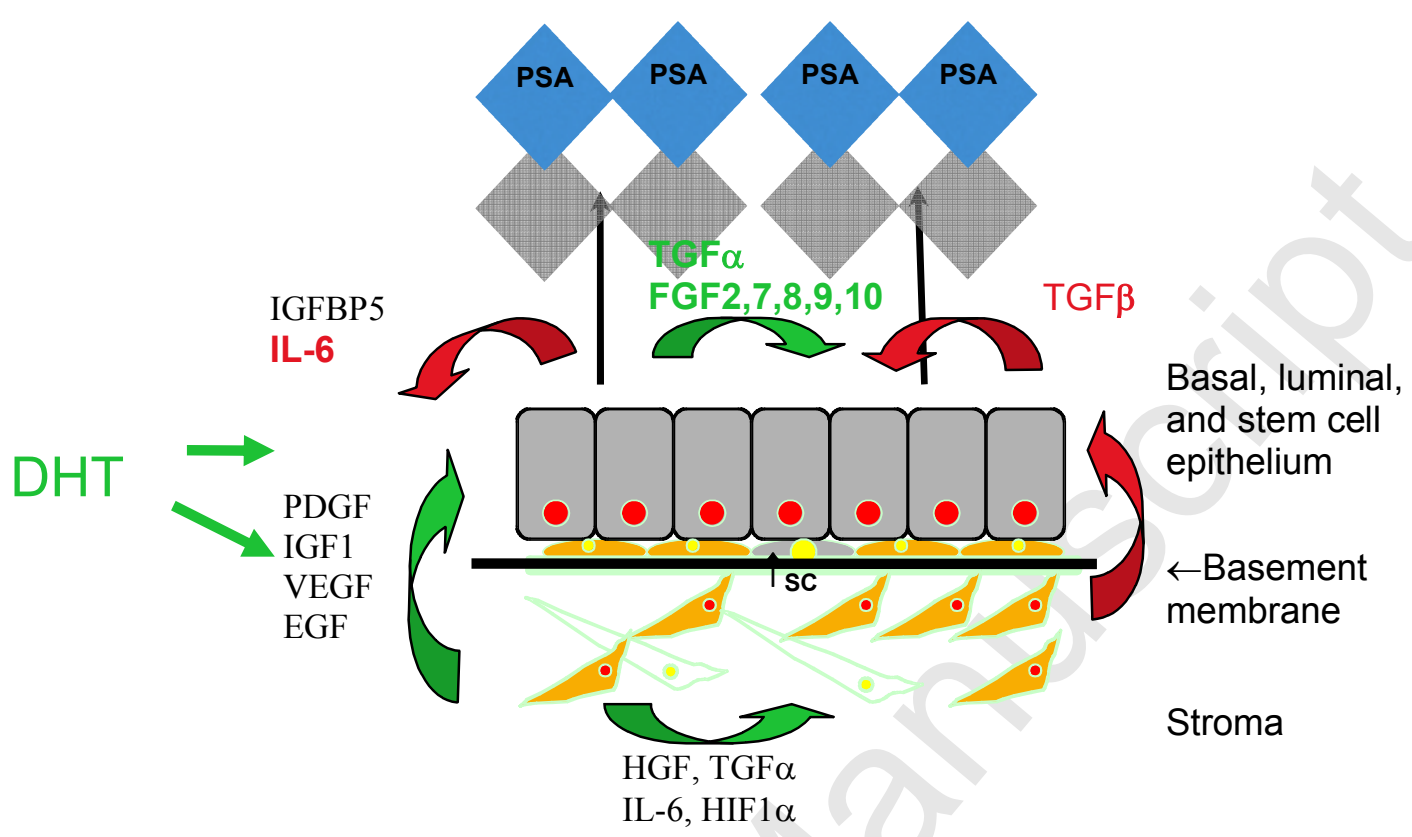

Figure 1. Stromal-epithelial interactions in the prostate.

The basal cells are in direct contact with the basement membrane. The cancer stem cell ( $\uparrow s c)$ is also shown. The stromal cells secrete multiple classes of growth factors important for maintenance of the prostate. Growth factors can be inhibitory (shown in red) or stimulatory (shown in green), some of these are androgen (DHT) regulated. Both cells within the stroma and the luminal epithelial cells within the basal cell compartment express AR. Luminal epithelial cells secrete PSA in response to DHT. 